ABDELWHAB MAHMOUD JADAAN RAWASHDEH, Assistant of Professor of Accounting Department Faculty of Economics and Administrative Sciences Zarqa University, Jordan

\title{
The Impact of Electronic Money Use on the Quality of Accounting
}

The definition of the term "electronic money" was analyzed. The use of electronic money in the context of its consideration in international accounting was studied. The basic theoretical and practical issues, which arise in accounting while displaying operations of the presence and movement of electronic money, were revealed. The priority areas to improve the methods of accounting payment transactions between counterparties when using electronic money were identified. The impact of electronic money on the quality of international accounting was outlined.

Key words: international means of payment, electronic payment systems, electronic money, accounting methods of electronic money, payment systems.

\section{Formulation of the problem}

The economic development of any state today is impossible without highly effective monetary system, the use of modern payment mechanisms. In a market in which it is abolished the centralized delivery of goods, vendors find an independent access to trading platforms for their products in search of the most profitable buyer (customer). When the desire of buyers and suppliers coincide, the partners conclude agreements (contracts) on the supply of goods, services or works; calculated relationships are established between them. Accordingly, the relevance of accounting payments due, primarily, to the fact that payment transactions is a prerequisite for entrepreneurship, based on contractual obligations and receivables or payables - it is their inevitable consequence, as there is almost always a gap in the time between the moment of payment and the moment of transfer of the right of ownership of the goods.

The internal and external users of financial statements are interested in getting reliable information about the financial condition of the company and its financial performance; they need to make informed management decisions [1].

Missing or incomplete statements to reflect data on performed payment transactions, requirements and obligations can lead to incorrect analytical calculations and incorrect conclusions regarding changes in asset turnover and other indicators of business activity, balance sheet liquidity and solvency in the short and long term perspective.

Today the interest of a growing number of experts in international accounting call accounting issues cashless payments. The development of the market economy and the emergence of new forms of financial relationships explain the need to improve the existing regulatory framework, bringing it closer to international practice.

\section{Analysis of recent research and publications.}

Review of publications shows that scientists are paying an increasing attention to the problems of the impact of the use of electronic money on the quality of international accounting. Thus, considerable interest are the works of A. Apcherch, L. A. Bernstein, N. Dorosh, Y. Bethe, J. Blake, R. Breuil, D. MakAndryus, L. Meier, J. Myddlton, M. R. Matyus, B. Nydlz, J. Richard, J. Halassy, V. V. Sopko, Art. Zeff, R. Matessych, V. A. Shevchuk, D. Humphrey.

Taking into international account these issues the purpose of this study is theoretical and methodological basis of electronic money international accounting, as well as its impact on the quality of accounting. To following tasks were identified: to investigate the definition of "electronic money", consider the characteristics of its operation and display, and determine how electronic money affects the quality of accounting.

Presentation of the main research.

Monetary tools exist in cash (the forms of currency are notes and coins) and in non-cash form (the form of entries in the accounts at banks). Non-cash payments are a transfer of a

(C) Abdelwhab Mahmoud Jadaan Rawashdeh, 2017 
certain amount of funds from the payer to the beneficiary of funds and transfer of banks on behalf of companies and individuals the funds deposited by them in cash to the bank to the accounts of funds recipients [6]. These calculations are made by the bank on the basis of settlement documents on paper or electronically. Cashless payments are carried out using current accounts opened in accordance with the instructions. This means moving from one counterparty credit directly to the other counterparty. To initiate payments the payment instruments are used. They represent money of certain form on paper, electronic or other carrier of information used to initiate the transfer. Payment instruments include the transfer documents and electronic means of payment.

Electronic money was introduced as a payment instrument more than 20 years ago. While the dynamics of its use was much slower than expected, mainly because of the costly introduction, a strong barrier at the later phase was complicated rules for electronic money.

According to the European Directive, electronic money - are the units of value stored on the electronic device and accepted as the means of payment by persons other than the person who issued them, and is the bonds of that person, which is done in cash or by bank transfer. The earliest regulation on circulation of electronic money was adopted in 2000 as a European directive for electronic money. This directive provided the earliest definitions of electronic money, its characteristics, and legal rules for creating and operating institutes of electronic money. The directive was aimed at setting competition between bank institutions and the institute of electronic money and creating stimuli for further innovations [4].

That is, the electronic money - it's not money, but some units of value. They are kept not on current accounts of bank customers but on the anonymous electronic devices. Regarding electronic money as a means of payment the concept of "means of payment" hasn't been defined in the International Law as the term legal tender". That suggests that these concepts are identical, and electronic money can be considered a kind of means of payment. Thus, the electronic money is not the money in the literal sense of the word but simply another way of settlement which has its own characteristics.

According to the definition of electronic money the bank that issued it takes the liability of redemption of electronic money presented to him. The use of electronic money in mutual settlements (i.e. between sellers and buyers for goods and services) - is entirely voluntary and is usually governed by mutual agreements between the parties. But when for some reason it's impossible to use electronic money, the contracting parties can demand repayment in national currency. Therefore, the parties to the contract, if necessary, have the right to conduct cash payments, and the receiving party has no right to refuse to accept cash in national currency, insisting on making payments exclusively using electronic money. These issues can also be regulated in the contract between the bank issuing electronic money and the trader. For example, with this caveat: "If you cannot, for whatever reasons provide goods or services to the user - an individual after committing the full payment, the merchant must reimburse the costs to the user - a natural person by the return of cash or electronic money or otherwise allowed by current legislation" [8] Thus, electronic money can be used as an alternative means of payment based on the agreement between the payer and the recipient, but the tool of calculations cannot be limited only by electronic money refusing the calculation with the use of cash. If the contract between the parties provided no payments by electronic money, neither party to the contract may use such estimates unilaterally.

The practices of euro area countries in use of electronic money are very effective, as they help each country in identifying and investigating new problems related with use of electronic money and introduction of new instruments for their use in banking. Bearing in mind that the digital era is yet to come, electronic money will bring about many debates and problems in the forthcoming future [7].

The systems electronic money is certainly a part of the electronic payment system. However, they have a specific set of the following characteristics:

1. On the basis of electronic money there is always the obligation of the issuer, taken as a means of payment and able to self-circulation outside the banking system. Issuance of these obligations is generally based on sales of the deposit to the issuer in the "traditional" money in the equivalent amount.

2. These commitments represent the flow of electronic data.

3. The key feature of electronic money is the possibility of instant, anonymous payments between parties without direct connection with the bank account. 
4. Electronic money can have a different degree of equivalence. They can be emitted for settlement as to a particular range of products from a particular seller (usually in such cases, the seller is also the issuer of electronic money) and to the general public goods / services (in such cases usually issuer is a financial institution).

5. Accounting of electronic money is usually conducted in specific units of account, other than the national currency (Web Money - wmr, wmz) and linked to real currency or states, or to a particular product (e.g. E-Gold - gold).

With regard to accounting the issue of electronic money settlement hasn't been resolved for many years that led to certain difficulties of its reflection in accounting.

In international accounting the term "electronic money" received the statutory procedure simultaneously with setting accounting of electronic money.

Electronic money for the purposes of accounting is understood as the unit of value which:

1) is stored on an electronic device;

2 ) is accepted as means of payment by persons other than the person who produces them;

3 is the liability of one person executed in cash or non-cash forms. Thus with the purpose of accounting single-purpose prepaid cards: discount card dealers, gas stations cards, tickets for travel in public transport, etc. are not considered electronic money and are accepted as means of payment only by their issuers.

The analysis has showed that an important issue in transactions with electronic money, is their recording in the accounting. For example, all transactions with electronic money issuance undertaken by banking institutions are not subject to taxation because they are classified as services for cash management services. However, according to international regulation, such services can be considered as services of settlement and cash services only for banks leaving in question the work of other participants of the electronic money system

Another problem is the reflection of transactions made with the use of electronic money in accounting conducted by business entities. For example, the problem is the norm laid down in Art. 291.6 of the Tax Code of Ukraine, according to which business entities that are single tax payers are forbidden to accept payment for the sold goods / services, other means of payment except cash and bank money. How to take electronic money as payment for goods / services and how to account it by other entities, and whether such operations are subject to taxation, Ukrainian legislation does not define it today [5]. This creates uncertainty for operation of electronic money in Ukraine and for companies seeking to use electronic money as a means of payment. As a result, a part of electronic payment suspends its withdrawal on the Ukrainian market, while others already working in the country are forced to resort to finding other legal solutions that allow I / O of money in the system and implementing payment transactions using other means.

So now in accounting standards there are no comments to display features of electronic money as well as payments with them. The lack of regulation of issues circulation of electronic money in accounting standards and tax law makes electronic payment systems operate at very complicated legal schemes to implement their activities within the law. This is a significant obstacle to the spread of the payment instrument.

The agreement with an operator of electronic money is required for electronic money settlements. Organizations use special accounts, online wallets, for this purpose.

However, a separate account to record online wallet transactions in bookkeeping documents is not envisaged by the instruction to the chart of accounts. From formal point, online wallet is not a conventional account of an organization

Because online wallet represents a special account, transactions with electronic money can be recorded on the account "Special bank accounts", with separate recording of the available foreign currency and its flows. It follows that when an organization has two accounts for electronic money settlements (foreign currency account and national currency account), then the respective subaccounts need to be opened. For example, subaccounts "Special account for electronic money settlements in foreign currency" and "Special account for electronic money settlements in national currency".

Analysis shows that European issuers of electronic money are subject to licensing, and their operation is subject to regulation by administrative offices of the country where electronic money is issued. The European passport allows each issuer of electronic money, which has obtained the license in one EU country, to operate across the EU territory [4]. 
Electronic money issued in one EU country can be spent on a commercial web-site in another EU country.

Most part of electronic money issuers is located in the U.K., Luxembourg, and Germany. The licensed suppliers of Internet payment services in the U.S. are called "cash services companies".

In Europe, control over electronic money issuers is exercised by Directive 2000/46/ EU [3]. According to it, the control aims to ensure rational and reasonable operation and financial stability of such issuers. The regulations specify obligations on the availability of primary capital, availability of money sufficient for fulfillment of all the financial liabilities on issued and unpaid electronic money, limitations on investment, obligations on rational and reasonable management, appropriate procedures of business management, accounting policy and mechanisms of internal control.

Directive 2000/46/EU provides for the simplified procedure of proper client inspection, specifying that when online wallet cannot be replenished the maximal amount of storage shall not exceed 150 euro, and when it can be replenished the total amount of transactions over a calendar year shall not exceed 2500 euro, except for the cases when an online wallet owner withdraws cash worth of 1000 euro or more in the same calendar year (Chapter 3 of Directive 2000/46/EU) [3].

As regards the effect of electronic money for the quality of accounting, this effect is very significant. The analysis shows that by now there has not been a single approach to their accounting and quality control. This raises urgent need in elaborating methodological guidelines for accounting of electronic money by use of best international approaches to quality management in accordance with International Accounting Standards and ISO 9000. The methodological guidelines need to include unified and standardized methods for analysis, allowing for accounting of electronic money with the high probability score.

The statistics shows that in the countries with higher GDP per capita tend to register an increasing number of non-cash payments. The causation in this case works in both ways. On the one hand a higher level of well-being and development of the financial system in richer countries encourage non-cash payments. On the other hand there are several reasons why the introduction of cashless payments contributes to the acceleration of economic development. Electronic payment instruments give access to all funds in the account, making consumption more comfortable and increase its volume.

Shopping networks use data on payments for each individual user discounts and bonuses for its clients. Issuers may offer bonus programs for card users to promote the use of this tool. Thus, retail also receives additional impetus to development. In its turn, the increased consumption leads to increased employment and economic growth (Fig. 1) [8].

The introduction of electronic payment means a reduction of operating costs and the economy as a whole. Maintenance of the cash payment system is associated with significant costs actually borne by the society.

These costs include the costs of the central bank to print paper money and maintain the interbank payments, government spending on oversight and prevention of crime in this area, the time by consumers and businesses to registering and settlements, costs of banks and contractors to maintain the physical infrastructure of currency, transportation of paper money, payment processing and so on.

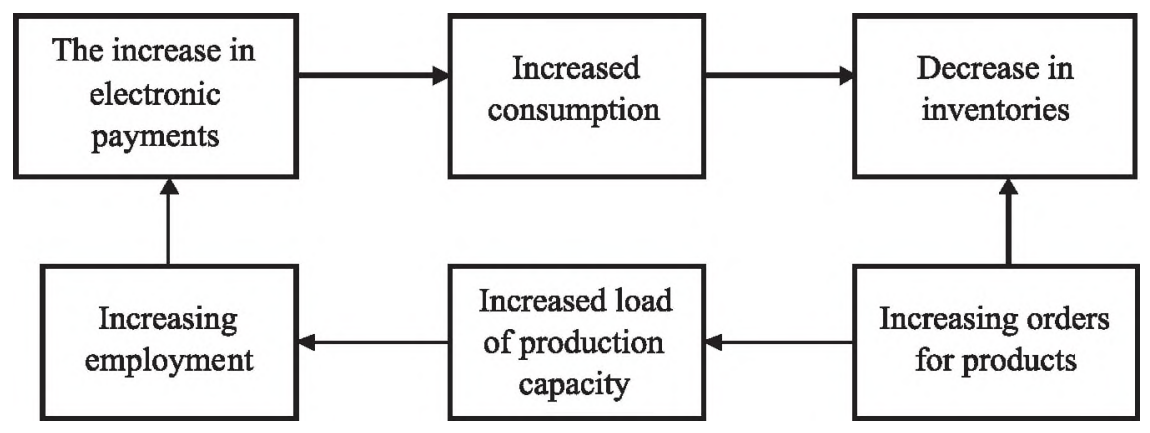

Fig. 1. The impact of electronic payments on economic growth Source: [8]. 
The cost of electronic payments compared with cash is generally rated as a lower one. This is due to several reasons. In particular when making electronic payment consumers spend less time carrying out transactions and do not have to spend time to get cash. Retailers do not carry the costs for collection and storage of cash, so consequently they can serve more customers and have less risk in obtaining funds. Banks reduce maintenance costs of physical cash.

Conclusions and future results.

In modern conditions to develop non-cash turnover is the main part of the calculations conducted between commercial partners. Mainly, this is due to the important economic role they perform, accelerating the reversibility of funds, lowering costs, reducing cash in circulation. In addition non-cash payments contribute to the concentration of free resources of banks being a source of financing. Separation of cash and non-cash money circulation creates conditions that facilitate the planning of cash flow.

The introduction of electronic payments helps attract funds of individuals and companies to the banking system and reduce cash flow. Widespread cashless payments make these tools more accessible and necessary for the general population.

Thus there increases the coverage of financial services that reduces the unproductive cash savings, stimulates small business development decreasing the role of shadow operations.

However it should be noted that the issue of electronic money accounting remains insufficiently investigated. Today there is a number of significant inconsistencies in the regulations governing the use of electronic money among themselves and on the order of its registration.

\section{References}

1. Arnone, M. \& Bandiera, L. (2004) Monetary Policy, Monetary Areas and Financial Development with Electronic Money, IMF, working paper 04/122.

2. Commission of the European communities (2008) Accompanying document to the proposal for a Directive of the European Parliament and of the Council amending Directive 2000/46/ EC on the taking up, pursuit of and prudential supervision of the business of electronic money institutions, Impact assessment, Commission staff working document.

3. European Commission (2006) Review of the E-Money Directive 2000/46/EC, commission staff working document, SEC (2006) 1049.

4. Halpin R., Moore R. Developments in electronic money regulation - the Electronic Money Directive: A better deal for e-money issuers? / Computer Law and Security Review, 25 (2009), 563-568.

5. Pofatkovuy kodeks. Retrieved from: http://zakon2.rada.gov.ua/laws/show/2755-17.

6. Popovska-Kamnar, N. The use of electronic money and its impact on monetary policy, JCEBI, Vol.1 (2014) No.2, pp. 79-92.

7. Wilusz, D., Legal determinants of electronic money systems development in European Union, in: Prawny i ekonomiczny przeglad prawa gospodarczego, vol. 2, ed. Dubiński, Ł.,Wydawnictwo Naukowe UAM, 2011, pp. 125-134.

8. Yatsuk T. V. (2017). Metoduka finansovogo obliku kruptovalyutu yak osobluvogo vudy elektronnuh groshey. Young Scientist, No 2 (42). Retrieved from: http://molodyvcheny. in.ua/files/journal/2017/2/81.pdf 
АБДЕЛВАХАБ МАХМУД ДЖАДАН РАВАЖДЕ, асистент професора кафедри бухгалтерського обліку факультету економіки і адміністративних наук,

Університет в м. Зарка, Йорданія

\section{Вплив використання електронних грошей на якість обліку}

Проаналізовано визначення «електронних гроией». Здійснено аналіз використання електронних грошей в контексті ӥх врахування в міжнародному бухгалтерському обліку. Виявлено основні проблемні питання теоретичного та практичного характеру, які виникають у міжнародному бухгалтерсъкому обліку під час відображсення операцій з наявності та руху електронних гроией. Визначено пріоритетні напрями вдосконалення методики обліку розрахункових операцій між контрагентами з використанням електронних гроией. Окреслено вплив електронних грочей на якість міжнародного бухгалтерського обліку.

Ключові слова: міжнародний засіб платежу, електронна розрахункова система, електронні гроиі, методика обліку електронних гроией, міжнародні платіжні системи.

АБДЕЛВАХАБ МАХМУД ДЖАДАН РАВАЖДЕ, ассистент профессора кафедры бухгалтерского учета факультета экономики и административных наук, Университет в г. Зарка. Иордапия

\section{Влияние использования электронных денег на качество учета}

Проанализировано определение «электронных денег». Осуществлен анализ использования электронных денег в контексте их учета в международном бухгалтерском учете. Выявлены основные проблемные вопросы теоретического и практического характера, которые возникают в межсдународном бухгалтерском учете при отражении операций наличия и движения электронных денег. Определены приоритетные направления совериенствования методики учета расчетных операций между контрагентами с использованием электронных денег. Определены влияние электронных денег на качество международного бухгалтерского учета.

Посилання на статтю:

Abdelwhab mahmoud jadaan Rawashdeh. The impact of electronic money use on the quality of accounting // Scientific Bulletin of National Academy of Statistics, Accounting and Audit: quarterly collection of scientific papers. 2017. No 1-2. P. 40-45. 